\title{
PENERAPAN METODE INKUIRI UNTUK MENINGKATKAN \\ HASIL BELAJAR IPS SISWA KELAS III SD NEGERI 168432 TEBING TINGGI
}

\author{
Nursamsiah \\ Surel: ibunursamsiah@gmail.com
}

\begin{abstract}
This study aims to improve the learning outcomes of students of IPS learning through inquiry learning method in class III SD Negeri 168432 Tebing Tinggi Academic Year 2016/2017. This type of research is a class action research (Action Research). Implementation of this research is done with two cycles. This research uses qualitative decriptive analysis technique and the tools used in data collection are daily test and student observation sheet and researcher. The subject of this research is the third grade students of SD Negeri 168432 with total 33 people. The object of this research is the use of inquiry method in improving IPS learning result in class III SD Negeri 168432 Tebing Tinggi.
\end{abstract}

Keywords: IPS, Inquiry, Learning Outcomes

\begin{abstract}
ABSTRAK
Penelitian ini bertujuan untuk meningkatkan hasil belajar siswa mata pelajaran IPS melalui metode pembelajaran inkuiri di kelas III SD Negeri 168432 Tebing Tinggi Tahun ajaran 2016/2017. Jenis penelitian ini adalah penelitian tindakan kelas (Action Research). Pelaksanaan penelitian ini dilakukan dengan dua siklus. Penelitian ini menggunakan teknik analisis dekriptif kualitatif dan alat yang digunakan dalam pengumpulan data adalah tes ulangan harian dan lembar observasi siswa dan peneliti. Subjek penelitian ini adalah siswa kelas III SD Negeri 168432 dengan jumlah 33 orang. Objek penelitian ini adalah penggunaan metode inkuiri dalam meningkatkan hasil belajar IPS di kelas III SD Negeri 168432 Tebing Tinggi.
\end{abstract}

Kata Kunci: IPS, Inkuiri, Hasil Belajar

\section{PENDAHULUAN}

Ilmu Pengetahuan Sosial (IPS) merupakan salah satu mata pelajaran yang diberikan di SD yang mengkaji seperangkat peristiwa, fakta, konsep, dan generalisasi yang berkaitan dengan isu sosial. Tujuan dari mata pelajaran IPS di SD yakni menggambarkan sasaran akhir yang hendak dicapai oleh siswa setelah mengikuti proses dan menyelesaikan pendidikan dalam program sekolah dasar. Berdasarkan hasil pengamatan awal peneliti dalam pembelajaran IPS, proses pembelajaran yang diterapkan guru masih berpusat pada guru yang terlihat dari pasifnya siswa selama proses pembelajaran, penggunaan metode pembelajaran yang kurang tepat sehingga antusias 
siswa dalam proses pembelajaran IPS kurang, siswa tidak berani menyatakan pendapat, dan semua berdampak pada rendahnya hasil belajar siswa.

Tujuan penelitian ini adalah untuk mengetahui penerapan metode inkuiri dalam meningkatkan hasil belajar siswa pada mata pelajaran IPS di kelas III SD Negeri 168432 Tebing Tinggi Tahun Ajaran 2016/2017.

\section{METODE PENELITIAN}

Penelitian tindakan kelas ini dilaksanakan di SD Negeri 168432 Tebing Tinggi Jalan Rumah Sakit Umum kelurahan Pasar Baru Kecamatan Tebing Tinggi Kota.

Subjek penelitian adalah siswa kelas III yang bersifat heterogen dengan jumlah siswanya 33 orang.

Waktu pelaksanaan penelitian adalah pada semester genap tahun ajaran 2016/2017, tepatnya bulan Februari sampai dengan April 2017. Analisis data penelitian dilakukan dengan teknik deskriptif. Instrumen penelitian adalah tes hasil belajar siswa yang dilaksanakan setiap akhir siklus dimaksudkan untuk mengukur hasil yang diperoleh siswa setelah pemberian tindakan.Penelitian ini menggunakan model penelitian berbentuk spiral dari siklus yang satu ke siklus yang berikutnya. Siklus spiral dari tahap-tahap penelitian tindakan kelas dapat dilihat pada gambar berikut:

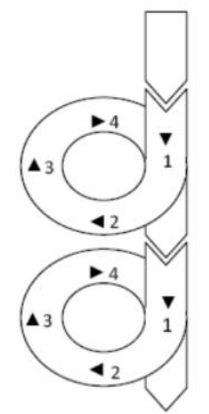

Siklus I: 1. Perencanaan I

2. Tindakan I.

3. Observasi I

4. Refleksi I.

Siklus II: 1. Revisi Rencana I

2. Tindakan II.

3.observasi II

4. Refleksi II

\section{Gambar. Model Penelitian Tindakan Kelas}

Pada tahap perencanaan peneliti melakukan aktivitas yaitu:

a. Membuat RPP.

b. Menganalisis materi pembelajaran.

c. Menyiapkan objek lingkungan.

d. Melakukan koordinasi dengan kepala sekolah dan rekan sejawat.

e. Menyiapkan lembar observasi.

f. Menyusun lembar observasi bagi siswa dan guru.

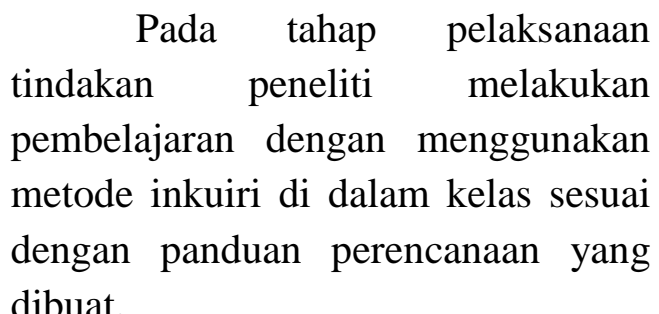

Pada tahap observasi guru atau peneliti dibantu seorang guru bertindak sebagai observator dengan menggunakan alat pendukung observasi seperti alat perekam, catatan lapangan, lembar observasi dan foto dokumentasi. Data yang diperoleh pada lembar observasi dianalisis kemudian dilakukan refleksi. 
Pelaksanaan refleksi merupakan hasil observasi atau pengamatan peneliti pada saat melakukan observasi di kelas yang bertujuan untuk mengevaluasi hasil tindakan yang telah dilakukan. Data Kuantitatif yang diperoleh melalui observasi atau pengamatan pelaksanaan tindakan, selanjutnya dianalisis dengan teknik hasil observasi aktifitas siswa selama PBM secara deskriptif menggunakan persentase.

Siklus II merupakan tindakan perbaikan dari siklus I yang masih belum berhasil. Pada siklus kedua ini juga diadakan perencanaan seperti pada siklus satu yaitu tahap perencanaan, tindakan, observasi dan refleksi dalam suatu konsep yang saling terkait. Hanya saja pada siklus kedua ini adaperubahan yang menuju kearah yang lebih baik jika dibandingkan dengan siklus satu.

Data yang diperoleh pada lembar observasi dianalisis lebih mendalam dan tajam dalam siklus kedua ini. Kemudian dilakukan refleksi atau perenungan.

Instrumen yang digunakan dalam penelitian ini terdiri dari:

a. RPP

b. Lembar Kegiatan Siswa

c. Lembar observasi kegiatan guru dan siswa menerapkan metode inkuiri d. Tes hasil belajar siswa

HASIL DAN PEMBAHASAN

Untuk mengetahui hasil penelitian langkah pertama peneliti adalah mengidentifikasi masalah melalui pengamatan proses belajar mengajar yakni rendahnya hasil belajar siswa.

\section{Tabel Hasil Belajar Siswa Kondisi} Awal

\begin{tabular}{|c|c|c|c|}
\hline No & Nilai & Frekuensi & Persentase \\
\hline 1 & $50-59$ & 4 & $12,12 \%$ \\
\hline 2 & $60-69$ & 7 & $21,21 \%$ \\
\hline 3 & $70-79$ & 14 & $42,42 \%$ \\
\hline 4 & $80-90$ & 8 & $24,24 \%$ \\
\hline
\end{tabular}

Data yang diperoleh melalui hasil tes ulangan pada pra siklus terlihat bahwa persentase ketuntasan belajar siswa yang mendapat nilai $>70$ adalah 22 siswa $(66,67 \%)$ dan nilai $<70$ adalah 11 siswa $(33,33 \%)$. Selanjutnya peneliti melakukan refleksi terhadap hasil yang diperoleh ini dengan melakukan tindakan siklus I melalui penerapan metodeinkuiri.

Dalam penelitian ini ada dua aspek yang ingin diukur yaitu pengelolaan pembelajaran dan hasil pembelajaran.

Adapun data hasil observasi kegiatan guru penelitian pada siklus I adalah sebagai berikut: 
Tabel Hasil Observasi Kegiatan Guru Pada Siklus I

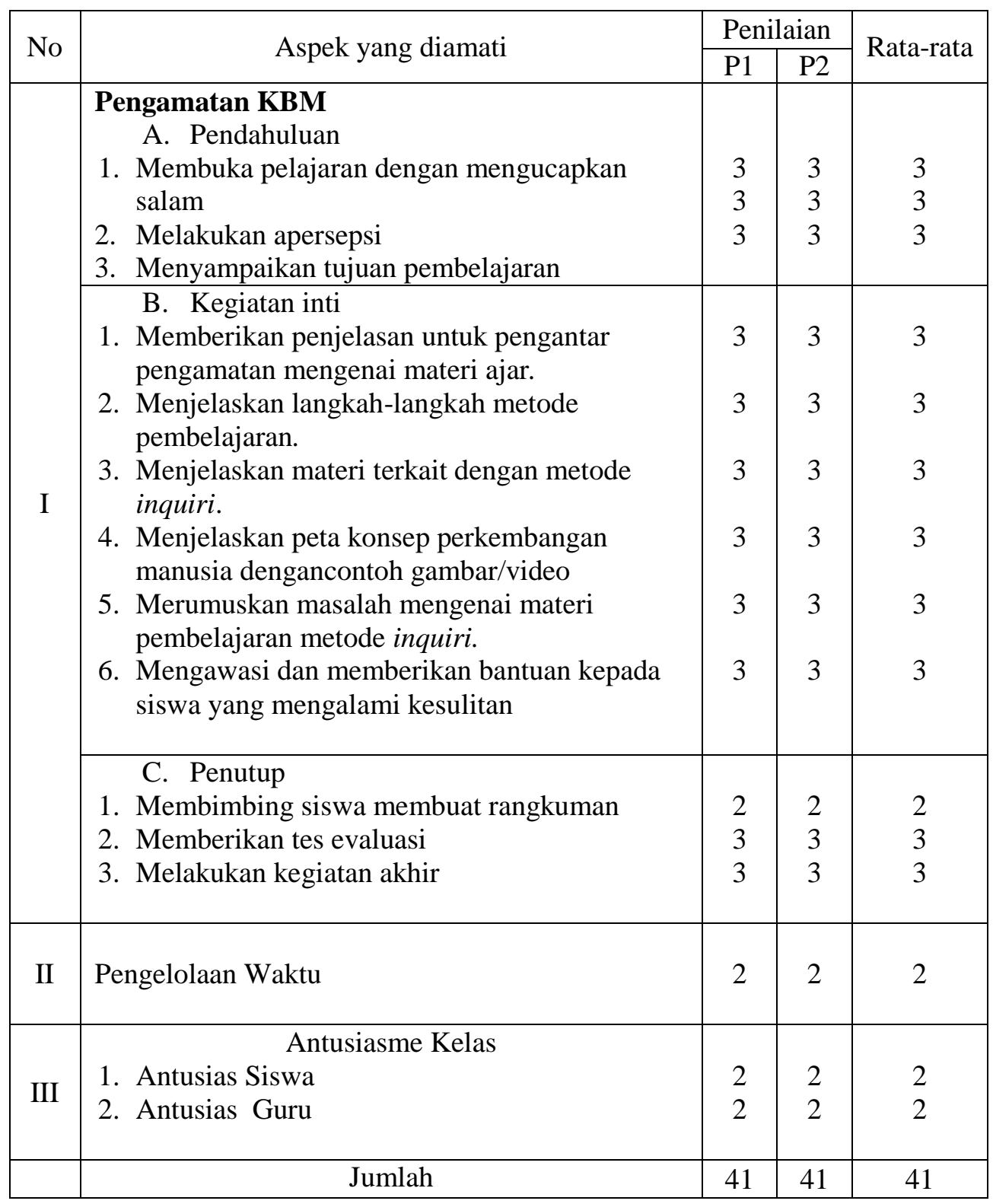

Keterangan :

$$
\begin{array}{ll}
1 & =\text { kurang baik } \\
2 & =\text { cukup } \\
3 & =\text { baik } \\
4 & =\text { sangat baik }
\end{array}
$$

Dalam penelitian ini aspekaspek kegiatan guru secara umum sudah dianggap baik oleh pengamat walaupun dalam beberapa kegiatan pembelajaran, guru hanya menyebutkan tujuan secara lisan tanpa menulis di papan tulis. Hanya saja pada aspek membimbing, siswa membuat rangkuman dan pengelolaan waktu masih tergolong cukup pengelolaan waktu kurang 
efektif terlihat waktu berakhirnya pelajaran maju 15 menit dari waktu yang telah ditetapkan. Selain mengamati aktivitas guru oleh observatory, peneliti juga melakukan pengamatan terhadap aktivitas siswa.

Adapun hasil pengamatan kegiatan siswa pada siklus I adalah sebagai berikut:

\section{Tabel Hasil Observasi Aktivitas Siswa Siklus I}

\begin{tabular}{|c|l|c|c|}
\hline No & \multicolumn{1}{|c|}{ Aktivitas siswa yang diamati } & $\begin{array}{c}\text { Presentase } \\
\text { Maksimal }\end{array}$ & $\begin{array}{c}\text { Presentase } \\
\text { Perolehan }\end{array}$ \\
\hline 1 & Mengucapkan salam & 10 & 8.7 \\
\hline 2 & $\begin{array}{l}\text { Mendengarkan/ memperhatikan penjelasan } \\
\text { materi dari guru }\end{array}$ & 10 & 8.2 \\
\hline 3 & Keantusiasan siswa mengikuti pelajaran & 10 & 7.7 \\
\hline 4 & $\begin{array}{l}\text { Membaca buku mengenai materi } \\
\text { pembelajaran }\end{array}$ & 10 & 8.0 \\
\hline 5 & $\begin{array}{l}\text { Mengamati konsep pertumbuhan dan } \\
\text { perkembangan bayi melalui gambar/video }\end{array}$ & 10 & 7.5 \\
\hline 6 & Mengerjakan soal latihan & 10 & 8.0 \\
\hline 7 & $\begin{array}{l}\text { Menuliskan dan menyampaikan hasil } \\
\text { pengamatan }\end{array}$ & 10 & 7.5 \\
\hline 8 & $\begin{array}{l}\text { Mengajukan pendapat/ ide, bertanya atau } \\
\text { berkomentar mengenai materi } \\
\text { pembelajaran }\end{array}$ & 10 & 7.7 \\
\hline 9 & Merangkum pembelajaran & 10 & 7.2 \\
\hline 10 & Mengerjakan tes evaluasi & 10 & 7.5 \\
\hline \multicolumn{2}{|l|}{ Persentase Aktivitas Siswa } & 78 \\
\hline
\end{tabular}

Keterangan : Nilai Persentase

Kriteria

$$
\begin{array}{ll}
86-100 \% & \text { Baik } \\
70-85 \% & \text { Cukup } \\
1-69 \% & \text { Kurang }
\end{array}
$$

Beberapa aspek yang mendapat nilai kurang baik di atas suatu kelemahan yang terjadi pada pada siklus I dan akan dijadikan bahan kajian untuk refleksi dan revisi yang akan dilakukan pada siklus II.

Distribusi hasil belajar siswa pembelajaran IPS melalui tes ulangan harian dapat dilihat pada tabel berikut: 
Nursamsiah: Penerapan Metode Inkuiri ..

Tabel Nilai Tes Ulangan Harian Siswa Siklus I

\begin{tabular}{|c|c|c|c|c|c|c|c|c|c|}
\hline \multirow{2}{*}{ No } & \multirow{2}{*}{$\begin{array}{l}\text { Kode } \\
\text { Siswa }\end{array}$} & \multirow{2}{*}{ Nilai } & \multicolumn{2}{|c|}{ Keterangan } & \multirow{2}{*}{ No } & \multirow{2}{*}{$\begin{array}{l}\text { Kode } \\
\text { Siswa }\end{array}$} & \multirow{2}{*}{ Nilai } & \multicolumn{2}{|c|}{ Keterangan } \\
\hline & & & $\mathrm{T}$ & TT & & & & $\mathrm{T}$ & TT \\
\hline 1 & 001 & 73 & $\sqrt{ }$ & & 18 & 018 & 60 & & $\sqrt{ }$ \\
\hline 2 & 002 & 65 & & $\sqrt{ }$ & 19 & 019 & 75 & $\sqrt{ }$ & \\
\hline 3 & 003 & 75 & $\sqrt{ }$ & & 20 & 020 & 72 & $\sqrt{ }$ & \\
\hline 4 & 004 & 70 & $\sqrt{ }$ & & 21 & 021 & 90 & $\sqrt{ }$ & \\
\hline 5 & 005 & 87 & $\sqrt{ }$ & & 22 & 022 & 82 & $\sqrt{ }$ & \\
\hline 6 & 006 & 65 & & $\sqrt{ }$ & 23 & 023 & 65 & & $\sqrt{ }$ \\
\hline 7 & 007 & 70 & $\sqrt{ }$ & & 24 & 024 & 85 & $\sqrt{ }$ & \\
\hline 8 & 008 & 65 & & $\sqrt{ }$ & 25 & 025 & 75 & $\sqrt{ }$ & \\
\hline 9 & 009 & 80 & $\sqrt{ }$ & & 26 & 026 & 90 & $\sqrt{ }$ & \\
\hline 10 & 010 & 74 & $\sqrt{ }$ & & 27 & 027 & 63 & & $\sqrt{ }$ \\
\hline 11 & 011 & 80 & $\sqrt{ }$ & & 28 & 028 & 80 & $\sqrt{ }$ & \\
\hline 12 & 012 & 75 & $\sqrt{ }$ & & 29 & 029 & 85 & $\sqrt{ }$ & \\
\hline 13 & 013 & 77 & $\sqrt{ }$ & & 30 & 030 & 80 & $\sqrt{ }$ & \\
\hline 14 & 014 & 80 & $\sqrt{ }$ & & 31 & 031 & 72 & $\sqrt{ }$ & \\
\hline 15 & 015 & 75 & $\sqrt{ }$ & & 32 & 032 & 60 & & $\sqrt{ }$ \\
\hline 16 & 016 & 80 & $\sqrt{ }$ & & 33 & 033 & 70 & $\sqrt{ }$ & \\
\hline 17 & 017 & 85 & $\sqrt{ }$ & & & & & & \\
\hline & Jumlah & 1276 & 14 & 3 & & Jumlah & 1204 & 12 & 4 \\
\hline $\begin{array}{l}\text { Juml } \\
\text { Juml } \\
\text { Nilai } \\
\text { Kete } \\
\text { Juml } \\
\text { Juml } \\
\text { Klasi }\end{array}$ & $\begin{array}{l}\text { Skor } \\
\text { Skor Mak } \\
\text { a-rata ula } \\
\text { gan: } \\
\text { siswa yan } \\
\text { siswa yan } \\
\end{array}$ & $\begin{array}{l}\text { al Ideal } \\
\text { hariar } \\
\text { htas } \\
\text { lum tur }\end{array}$ & $\begin{array}{r}248 \\
3300 \\
5,15\end{array}$ & & & & & & \\
\hline
\end{tabular}

Dari tabel di atas diperoleh nilai rata-rata ulangan harian siswa adalah 75,15 dan ketuntasan belajar mencapai $78,78 \%$ atau ada 26 siswa dari 33 siswa sudah tuntas belajar. Hasil tersebut menunjukkan bahwa pada siklus pertama secara klasikal siswa belum tuntas belajar, atau masih di bawah tingkat keberhasilan yang diharapkan yaitu $85 \%$. Oleh karena itu perlu dilanjutkan ke siklus II. Siklus II dilakukan pada tanggal 10 Maret 2017 dengan jumlah siswa 33 orang di kelas III. Dalam siklus II dilakukan revisi sehingga kesalahan pada siklus I tidak terulang lagi. 
Selain melakukan observasi aktivitas siswa juga dilakukan observasi pada kegiatan guru dalam pembelajaran
IPS dengan menggunakan metode inkuiri. Adapun data hasil penelitian pada siklus II adalah sebagai berikut:

Tabel Hasil Observasi Kegiatan Guru Siklus II

\begin{tabular}{|c|c|c|c|c|}
\hline \multirow{2}{*}{ No } & \multirow{2}{*}{ Aspek yang diamati } & \multicolumn{2}{|c|}{ Penilaian } & \multirow{2}{*}{ Rata-rata } \\
\hline & & P1 & $\mathrm{P} 2$ & \\
\hline \multirow{17}{*}{ I } & Pengamatan KBM & & & \\
\hline & Pendahuluan & & & \\
\hline & $\begin{array}{l}\text { 1. Membuka pelajaran dengan } \\
\text { mengucapkan salam }\end{array}$ & 4 & 4 & 4 \\
\hline & 2. Melakukan apersepsi & 3 & 3 & 3 \\
\hline & 3. Menyampaikan tujuan pembelajaran & 3 & 3 & 3 \\
\hline & Kegiatan inti & & & \\
\hline & $\begin{array}{l}\text { 1. Memberikan penjelasan untuk pengantar } \\
\text { pengamatan mengenai materi ajar. }\end{array}$ & 4 & 4 & 4 \\
\hline & 2. Menjelaskan langkah-langkah metode & 3 & 3 & 3 \\
\hline & $\begin{array}{l}\text { 3. Menjelaskan materi terkait dengan } \\
\text { metode inquiri. }\end{array}$ & 3 & 3 & 3 \\
\hline & $\begin{array}{l}\text { 4. Menjelaskan petak } \\
\text { perkembangan manusia dengan }\end{array} \begin{array}{l}\text { konsep } \\
\text { contoh }\end{array}$ & 3 & 3 & 3 \\
\hline & gambar/video & 3 & 3 & 3 \\
\hline & $\begin{array}{l}\text { 5. Merumuskan masalah mengenai materi } \\
\text { pembelajaran metode inquiri. }\end{array}$ & $J$ & & \\
\hline & $\begin{array}{l}\text { 6. Mengawasi dan memberikan bantuan } \\
\text { kepada siswa yang mengalami kesulitan }\end{array}$ & 3 & 3 & 3 \\
\hline & Penutup & & & \\
\hline & 1. Membimbing siswa membuat rangkuman & 3 & 3 & 3 \\
\hline & 2. Memberikan tes evaluasi & 3 & 3 & 3 \\
\hline & 3. Melakukan kegiatan akhir & 3 & 3 & 3 \\
\hline II & Pengelolaan Waktu & 3 & 3 & 3 \\
\hline \multirow{3}{*}{ III } & Antusiasme Kelas & & & \\
\hline & 1. Antusias Siswa & 3 & 3 & 3 \\
\hline & 2. Antusias Guru & 3 & 3 & 3 \\
\hline & Jumlah & 47 & 47 & 47 \\
\hline
\end{tabular}

Keterangan :

Kriteria : Nilai

$1=$ Kurang Baik

$2=$ Cukup

$3=$ Baik

$4=$ Sangat Baik
Dari tabel di atas aspek-aspek kegiatan guru mengalami peningkatan dibandingkan dengan siklus sebelumnya. Aspek yang mengalami peningkatan adalah membuka pelajaran dengan mengucapkan salam, membimbing siswa membuat rangkuman, penjelasan untuk 
Nursamsiah: Penerapan Metode Inkuiri ..

pengantar pengamatan mengenai materi ajar dan pengelolaan waktu.

Pengamatan (observasi) pengamatan yaitu penilaian kegiatan guru dan siswa oleh peneliti/observator. Adapun hasil dilaksanakan bersamaan dengan pengamatan kegiatan siswa pada pelaksaaan belajar mengajar. Data siklus II adalah sebagai berikut: lembar observasi diambil dari dua

Tabel Hasil Observasi Aktivitas Siswa Siklus II

\begin{tabular}{|c|c|c|c|}
\hline No & Aktivitas siswa yang diamati & $\begin{array}{l}\text { Presentase } \\
\text { Maksimal }\end{array}$ & $\begin{array}{l}\text { Presentase } \\
\text { Perolehan }\end{array}$ \\
\hline 1 & Mengucapkan salam & 10 & 9.5 \\
\hline 2 & $\begin{array}{l}\text { Mendengarkan/memperhatikan penjelasan materi } \\
\text { dari guru }\end{array}$ & 10 & 8.5 \\
\hline 3 & Keantusiasan siswa mengikuti pelajaran & 10 & 8.0 \\
\hline 4 & Membaca buku mengenai materi pembelajaran & 10 & 8.3 \\
\hline 5 & $\begin{array}{l}\text { Mengamati konsep keseimbangan ekosistem } \\
\text { melalui gambar/video }\end{array}$ & 10 & 8.0 \\
\hline 6 & Mengerjakan soal latihan & 10 & 8.4 \\
\hline 7 & Menuliskan dan menyampaikan hasil pengamatan & 10 & 8.3 \\
\hline 8 & $\begin{array}{l}\text { Mengajukan pendapat/ ide, bertanya atau } \\
\text { berkomentar mengenai materi pembelajaran }\end{array}$ & 10 & 8.3 \\
\hline 9 & Merangkum pembelajaran & 10 & 9.0 \\
\hline 10 & Mengerjakan tes evaluasi & 10 & 9.2 \\
\hline & Persentase Aktivitas Siswa & 100 & 85,5 \\
\hline
\end{tabular}

Keterangan :

Nilai Persentase : Kriteria $80-100 \% \quad$ Sangat Baik

$$
\begin{array}{ll}
65-79 \% & \text { Cukup Baik } \\
1-64 \% & \text { Kurang }
\end{array}
$$

Setelah melakukan ulangan harian pada akhir siklus II pembelajaran dengan menggunakan metode inkuiri, pada akhir pertemuan dilakukan tes Hasil belajar siswa pembelajaran IPS melalui tes ulangan harian dapat dilihat pada tabel berikut: 
Tabel Nilai Tes Ulangan Harian Siklus II

\begin{tabular}{|c|c|c|c|c|c|c|c|c|c|}
\hline \multirow{2}{*}{ No } & \multirow{2}{*}{$\begin{array}{l}\text { Kode } \\
\text { Siswa }\end{array}$} & \multirow{2}{*}{ Nilai } & \multicolumn{2}{|c|}{ Keterangan } & \multirow{2}{*}{ No } & \multirow{2}{*}{$\begin{array}{l}\text { Kode } \\
\text { Siswa }\end{array}$} & \multirow{2}{*}{ Nilai } & \multicolumn{2}{|c|}{ Keterangan } \\
\hline & & & $\mathrm{T}$ & TT & & & & $\mathrm{T}$ & TT \\
\hline 1 & 001 & 75 & $\sqrt{ }$ & & 18 & 018 & 67 & & $\sqrt{ }$ \\
\hline 2 & 002 & 73 & $\sqrt{ }$ & & 19 & 019 & 75 & $\sqrt{ }$ & \\
\hline 3 & 003 & 75 & $\sqrt{ }$ & & 20 & 020 & 74 & $\sqrt{ }$ & \\
\hline 4 & 004 & 75 & $\sqrt{ }$ & & 21 & 021 & 90 & $\sqrt{ }$ & \\
\hline 5 & 005 & 87 & $\sqrt{ }$ & & 22 & 022 & 82 & $\sqrt{ }$ & \\
\hline 6 & 006 & 70 & & $\sqrt{ }$ & 23 & 023 & 72 & & $\sqrt{ }$ \\
\hline 7 & 007 & 70 & $\sqrt{ }$ & & 24 & 024 & 80 & $\sqrt{ }$ & \\
\hline 8 & 008 & 74 & $\sqrt{ }$ & & 25 & 025 & 75 & $\sqrt{ }$ & \\
\hline 9 & 009 & 84 & $\sqrt{ }$ & & 26 & 026 & 90 & $\sqrt{ }$ & \\
\hline 10 & 010 & 74 & $\sqrt{ }$ & & 27 & 027 & 70 & $\sqrt{ }$ & \\
\hline 11 & 011 & 80 & $\sqrt{ }$ & & 28 & 028 & 78 & $\sqrt{ }$ & \\
\hline 12 & 012 & 73 & $\sqrt{ }$ & & 29 & 029 & 80 & $\sqrt{ }$ & \\
\hline 13 & 013 & 77 & $\sqrt{ }$ & & 30 & 030 & 80 & $\sqrt{ }$ & \\
\hline 14 & 014 & 80 & $\sqrt{ }$ & & 31 & 031 & 72 & $\sqrt{ }$ & \\
\hline 15 & 015 & 75 & $\sqrt{ }$ & & 32 & 032 & 65 & & $\sqrt{ }$ \\
\hline 16 & 016 & 80 & $\sqrt{ }$ & & 33 & 033 & 70 & $\sqrt{ }$ & \\
\hline 17 & 017 & 85 & $\sqrt{ }$ & & & & & & \\
\hline & Jumlah & 1307 & 16 & 1 & & Jumlah & 1220 & 14 & 2 \\
\hline $\begin{array}{l}\text { Jum } \\
\text { Jum } \\
\text { Nila }\end{array}$ & \multicolumn{9}{|c|}{$\begin{array}{l}\text { Jumlah Skor } 2527 \\
\text { Jumlah Skor Maksimal Ideal } 3300\end{array}$} \\
\hline \multicolumn{10}{|c|}{ Keterangan: } \\
\hline \multicolumn{5}{|c|}{ Jumlah siswa yang tuntas } & \multicolumn{5}{|c|}{30} \\
\hline \multicolumn{5}{|c|}{ Jumlah siswa yang belum tuntas } & \multicolumn{5}{|c|}{3} \\
\hline \multicolumn{5}{|c|}{ Klasikal } & \multicolumn{5}{|c|}{ Tuntas } \\
\hline
\end{tabular}

Dari tabel di atas dapat dijelaskan bahwa dengan menerapkan metode pembelajaran inquiri diperoleh nilai rata-rata ulangan harian siswa adalah 76,57 dan ketuntasan belajar mencapai 90,90\% atau ada 30 siswa dari 33 siswa sudah tuntas belajar. Terjadi 
peningkatan hasil belajar dari siklus sebelumnya.Hasil tersebut menunjukkan bahwa pada siklus kedua secara klasikal siswa sudah tuntas belajar, karena siswa yang memperoleh nilai $\geq 70$ sebesar 90,90\% melebihi dari persentase ketuntasan yang dikehendaki yaitu sebesar 85\%. Hasil observasi menunjukkan bahwa pembelajaran dengan menggunakan metode inquiri sudah berjalan semakin baik, peneliti sudah bisa mengarahkan siswa untuk bisa kerja secara kelompok dan melakukan kegiatan pembelajaran dengan metode inkuiri.Siswa merumuskan hipotesis sesuai dengan permasalahan yang dibuat dalam rumusan masalah. Siswa aktif dalam berdiskusi dan bekerja sama dengan baik dalam kelompok untuk merumuskan hipotesis.

Hasil pengamatan guru selama melakukan pembelajaran pada siklus I dengan penerapan metode inkuiri sudah dilaksanakan dengan baik, walaupun peran guru masih dominan dalam memberikan penjelasan dan arahan, karena metode ini masih baru dirasakan siswa. maka dilakukan perbaikan pada siklus II.Tindakan siklus II dilaksanakan, hasil siklus II terlihat terjadi peningkatan jika dibandingkan dengan hasil yang diperoleh pada siklus I. Pada siklus II guru telah mengelola kelas dengan baik sehingga terjadi peningkatan aspek-aspek kegiatan dari siklus sebelumnya. Peningkatan itu dapat terlihat pada proses dan hasil pembelajaran. Aktivitas siswa pada siklus II mengalami peningkatan. Secara garis besar kegiatan belajar mengajar dengan metode pembelajaran inquiri dilaksanakan terjadi peningkatan ke dalam kategori baik.

Hasil tes akhir siklus I yang dilakukan mengalami peningkatan walaupun masih ada 7 orang siswa yang belum tuntas. Hal ini dapat dilihat dari nilai ulangan harian yang diperoleh nilai rata-rata kelas pembelajaran siklus I menunjukkan peningkatan bila dibanding dengan pra tindakan, yaitu dari 22 siswa $(66,67 \%)$ yang tuntas belajar menjadi 26 siswa $(78,78 \%)$ pada siklus I kemudian pada siklus II meningkat menjadi 30 siswa yang tuntas (90,90\%). Dari hasil tes ini dapat disimpulkan bahwa dengan penerapan metode inquiri dalam pembelajaran IPS dapat meningkatkan hasil belajar siswa dan telah sesuai dengan indikator yanng telah ditentukan sehingga tidak perlu lagi dilanjutkan pada siklus berikutnya dan dinyatakan berhasil.

\section{SIMPULAN}

Dari hasil temuan penelitian tentanghasil belajar siswa dengan metode inkuiri di kelas III SD Negeri 168432 Tebing Tinggi tahhun ajaran2016/2017 berdampak positif dalam meningkatkan keterampilan guru danhasil belajar siswa. Hal tersebut dapat dilihat dari peningkatan persentase ketuntasan belajar siswa 
pada pra siklus $(66,62 \%)$, siklus I $(78,78 \%)$ dan siklus II $(90,90 \%)$.

\section{DAFTAR RUJUKAN}

Depdiknas. 2004. Peningkatan Kualitas Pembelajaran. Direktorat Jenderal Pendidikan Tinggi. Jakarta.

Djamarah, S. B. 2002. Rahasia Sukses Belajar. Jakarta: PT. Rineka cipta.

Budiningsih, Asri. 2005. Belajar dan Pembelajaran. Jakarta: Rineka Cipta

Kunandar.2013. Langkah Mudah Penelitian Tindakan Kelas Sebagai Pengembangan Profesi Guru.Jakarta: Raja Grafindo Persada.

Mukaromah, M. A. 2014. Penerapan Strategi Pembelajaran Inkuiri Pada Tema Lingkungan Untuk Meningkatkan Hasil Belajar IPS Siswa Kelas VI SD Negeri Perumnas 3 Depok Tahun Pelajaran 2012/2013. Skripsi. Universitas Negeri Yogyakarta.

Muhibbin Syah. 2002. Psikologi Belajar. Jakarta: PT Raja GrafindoPersada.

Sagala. 2004. Konsep dan Makna Pembelajaran. Bandung: Penerbit Alfabeta.

Sapriya. 2009. Pendidikan IPS. Bandung: PT Remaja Rosdakarya.
Sanjaya, W. 2008.Strategi Pembelajaran Berorientasi Standar Proses Pendidikan.Jakarta: Kencana Prenada Media.

Solihatin, E. dan Raharjo. 2007. Cooperative Learning. Jakarta: Bumi Aksara.

Sumantri, M dan Johar Permana. 2000. Strategi Belajar Mengajar. Jakarta: Dirjen Dikti Depdikbud.

Sudjana, N. 2009.Pendidikan Hasil Proses Mengajar. Bandung: PT. Remaja Rosdakarya.

Supriatna, N. dkk. 2007. Bahan Belajar Mandiri Pendidikan IPS di SD. Bandung: UPI Press.

Suprijono, Agus. 2014. Cooperative Learning Teori \& Aplikasi PAIKEM. Yogyakarta:

Pustaka Pelajar.

Trianto. 2010. Mendesain Model Pembelajaran Inovatif Progresif. Jakarta: Kencana Pernada Media Group.

Vanbela, V. 2016. Penerapan Metode Inkuiri Untuk Meningkatkan Aktivitas Dan Hasil Belajar Pada Pelajaran IPS Siswa Kelas $V$ SDN 4 Metro Selatan. Skripsi. Univesitas Lampung. 